\title{
GLOBALIZING SECURITY CLASSES USING GOOGLE TRENDS
}

\author{
Barbara Jo White, Western Carolina University,whiteb@email.wcu.edu \\ Mary Charles Hale, AmeriCorps, mchale@ncsu.edu \\ Lorrie Willey, Western Carolina University, lwilley@email.wcu.edu
}

\begin{abstract}
Globalization or internationalization of information systems courses is supported not only by the Association to Advance Collegiate Schools of Business but also by model curriculum guidelines for undergraduate programs in information systems. Though globalization of the information systems curricula is often mentioned in conjunction with a general IS course or a course in IS project management or software development, IT security courses are also ideal areas that can be globalized. This paper explores the use of Google Trends, a free tool displaying search trends with associated news stories and heat maps for each entered term or phrase, as a means of finding appropriate supplemental materials to help globalize security courses in undergraduate IS programs.
\end{abstract}

Keywords: Information Security, Globalization, Internationalization

\section{INTRODUCTION}

As business continues to move to global status, there are demands on schools of business to provide students with some of the knowledge and skills that will be needed to work and compete in the global business arena. Technology plays a significant role in the expansion of business activities across borders [5], so it is natural that information systems (IS) students need to have a global understanding of the world which technology created and in which technology will play a continuing major role. While obstacles to introducing global perspectives exist, current events involving global IS activities are an effective means by which to supplement traditional course materials. It is particularly suitable to use such materials in an IS security class since security is by its nature a cross-border international concern. The use of Google Trends can assist in identifying current materials that will add an international slant to the class.

\section{Globalization in Business Education}

The globalization of business "describes the opening up of national economies to global markets and global capital, the freer movement and diffusion of goods, services, finance, people, knowledge and technology around the world," [18 p. 65]. In essence, globalization reflects a worldwide "interconnectedness" and by its nature includes global problems that students will one day be expected to resolve [23, p. 123]. As they enter the workplace, students will be expected to "practice one's profession in an international setting" [28, p. 9] That international setting might even be within the borders of the US with a student's future employ[er] a foreign business organization with offices within the US [13]. U.S. organizations are conducting business overseas and establishing operation centers in foreign lands and send new employees to work at those centers [29]. Moreover, even when working with the US, students will be asked to "collaborate with partners (foreign), [and] seek new markets for their products..." [21, p. 200].

A major factor in the growth of business globalization is the fact that distance is no longer a barrier to international business operations [6]. It is no surprise that technology played and continues to play the major role in the evergrowing globalization of business, primarily in view of the technological advancements in communications [4]. Changes to international business operations are made possible by technology and those changes increase development of and accessibility to global markets and global services [4]. "Technology is transforming the way we do business..." [6, p. 56].

Are business schools providing students with the global business knowledge they need to do business in this transformed world? In 2011 the Association to Advance Collegiate Schools of Business (AACSB) released a study addressing the state of globalization in business education [2]. In that study, six categories of distinction between business operations internationally emerged: "cultural, legal/regulatory, political, economic, and financial and ...other" [8, p. 238]. The AACSB report defines globalization as a "process" of "extending the reach of educational engagement beyond one's home borders and deepening the richness of understanding about the increasingly global 


\section{Issues in Information Systems}

Volume 15, Issue II, pp. 39-48, 2014

foundation of business" [2, p. 7]. The IS profession covers the gambit of those categories so by its nature, IS education must include some global components. The failure to address the internationalization of business in college programs could result in those programs becoming "obsolete" [19 p. 18].

The AACSB process of globalization of business education represents more than just knowledge of business operations in other countries but demands a cultural understanding of the peoples, cultures and systems with which business will expect students to one day work [Parkinson]. In practice, international business understands how to interact and collaborate with those from different backgrounds, cultures and belief systems. “...[S]kills and experiences useful in working effectively with people from 'foreign' countries are going to become increasingly important" [6 p. 66]. Globalization of education must then support some level of awareness or competency in these areas.

The AACSB report clarified that there were various ways in which business schools can incorporate "global content" $[8$, p. 233] and that "[O]ne size does not fit all" [8, p. 233] when developing courses with international content. Of course, there are significant obstacles to the development of a global curriculum, from financial limitations [2] to faculty lacking international knowledge, research and experience. Despite these obstacles, exposing students to global events in relation to their studies is an important aspect of their education, even if only to encourage them to "at the minimum... attain global understanding" [19, p.16].

Using supplemental materials involving course-related global events as additional assigned readings or activities is an inexpensive way to turn an IS class into one in which the students will begin to develop the global understanding and the awareness of their world and profession. Incorporating these materials into a class will assist students in making connections between classroom studies and the world beyond the classroom [40]. Moreover, materials involving business globally also makes course content more relevant to the world in which students will be employed. Making a course more relevant to the professional and personal aspirations of students will allow them to see increased value in the content of the course [24]. Use of current events as the source of supplemental materials further increases student interest [37] and when the current events involved an international matter, provide students with increased competency in global knowledge [17]. Finding current event supplemental materials to globalize a class is as easy as going online.

\section{Globalization in Information Systems Curricula}

Adding relevant global supplemental materials in an IS security class is particularly meaningful. Data security is by definition a cross-border international concern. Security attacks and breaches cross borders and often occur with coordination of those in various countries [20]. Efforts to halt and mitigate attacks are taken not in isolation, but on a worldwide scale involving multiple nations [20]. The actions of one country in securing data from attacks, impacts the vulnerability or strength of another country [20]. The global threats to the US and other countries are continually growing, with one study indicating a $600 \%$ increase of malicious web links in 2012 [33]. Another recent study, illustrating the international aspect to cyber-attacks, indicates that while China remains a major source of data security concern, Iran and Syria are nations to be viewed as sources of increasingly powerful global security threats [10]. It is a natural fit to incorporate a global component involving current events into an IS security class. The issue of globalization in the business and specifically, the information systems curriculum is not new. As early as the 1990s, IS researchers were calling for globalization to become part of the IS curriculum. Integrating global/international components typically occurs via separate internationally-related courses or by incorporating international components into existing courses [5]. The IS/IT courses that could include international components included courses in the following: telecommunications; database management systems, especially distributed systems; Analysis, design and implementation of global systems, and global support systems; and IT courses centering information management, interpersonal skills and group decision making [5].

Besides research into globalization of the IS curriculum, another important source that shows how globalization (and other topics) have impacted the curriculum over time is any of the model curriculum guidelines that have been developed. In the IS/IT field, model curriculum guidelines for undergraduate degree programs in information systems have been produced since 1997 [12] by the Association for Information Systems (AIS) working in collaboration with the Association for Computing Machinery (ACM). Typically, the model curriculum guidelines, which range in length from 60 to 300 pages, contain narrative information as well as suggested course descriptions 


\section{Issues in Information Systems}

Volume 15, Issue II, pp. 39-48, 2014

and topics. After the first collaboration between the AIS and the ACM, which produced the 1997 model curriculum guidelines [12], a minor update followed in 2002 [16], and then a major update in 2010 [16]. Across the three model curricula, while some IS/IT aspects have remained relatively constant, such as a focus on IS projects in the classroom [39], other areas have shown an increase, such as the topic of security [43]. For example, the 2010 guidelines marked the first time a security class was included as a sample elective class in addition to the topic of security being included in six of the seven core classes in the guidelines.

By the same token, the terms global and globalization have gained a more central focus across the three model curriculum guidelines [12, 16, 41]. In 1997, though globalization appeared in the context of telecommunications strategy, for example, it did not appear in reference to global events or changes in security. While the model curriculum acknowledges that business courses should address international considerations, no requirements are included in the 1997 curriculum [12]. One of the driving forces behind the 2002 update to the model curriculum guidelines was e-commerce and an increasingly global, connected workforce [16]. The 2002 model curriculum includes suggested topics such as business models in a global world, operating in culturally diverse environments and global systems integration, particularly in the realm of e-commerce. The words global or globalization, international or internationalization appear over twenty times each in the 2002 and 2010 model curriculum guidelines. In 2002, the terms are included as a topic or part of a topic in three of the core classes (an e-business strategy course, a networking and telecommunications course, and a foundation of IT course, a project management course and a IS strategy course) in the model curriculum guidelines [16]. Globalization also served as a driver for the 2010 update, especially the increasingly global business environment and globally distributed IS teams, projects and IS programs. By 2010, the terms global or globalization appear in three of the core classes: a foundation of information systems course, a project management course and an IS strategy, management and acquisition course. In addition, the terms global or globalization also appear in two elective course outlines: a course in enterprise systems and a course in innovation and new technologies [41]. It is curious that the terms global or globalization do not appear in the elective information systems security class, or in several other core courses such as a data and information management class, an information architecture class, an information technology infrastructure class or the systems analysis and design course. Given the emphasis on including skills to thrive in a competitive global environment in the 2010 model curriculum guidelines, it is surprising that there is no mention of global or globalization in the information systems security class.

This paper will describe how instructors in information security courses can identify supplemental materials to help augment their courses. Specifically, we show how supplemental materials can include Google Trends and associated international news stories to globalize typical topics in an introductory information systems course.

\section{METHOD}

Generally, the method used to obtain materials to globalize IS security courses involved a textbook analysis followed by global search trend data collection using Google Trends for security topics in all or most of the texts that were common to the 2010 model curriculum guidelines [41]. In order to globalize the IS security class, the method included the following steps:

1. Determine the topics in IS Security model guidelines curricula that were also common to a typical sample of information security textbooks used in college courses.

2. Enter each term in Google Trends

3. Note heat map results and news items that correspond to peaks in search interest

4. Find corresponding news articles using the Google search engine with the news filter.

\section{RESULTS}

First, a search of topics from the information security class in the 2010 information systems model curriculum guidelines [41] was conducted by examining the tables of contents from five typical security texts used in undergraduate IS security courses $[7,11,30,31,42]$ and appear in Table 1 on the following page. 
Table 1. Topics in IS Security Model Curriculum Guideline Course as Covered by Sample of Security Texts

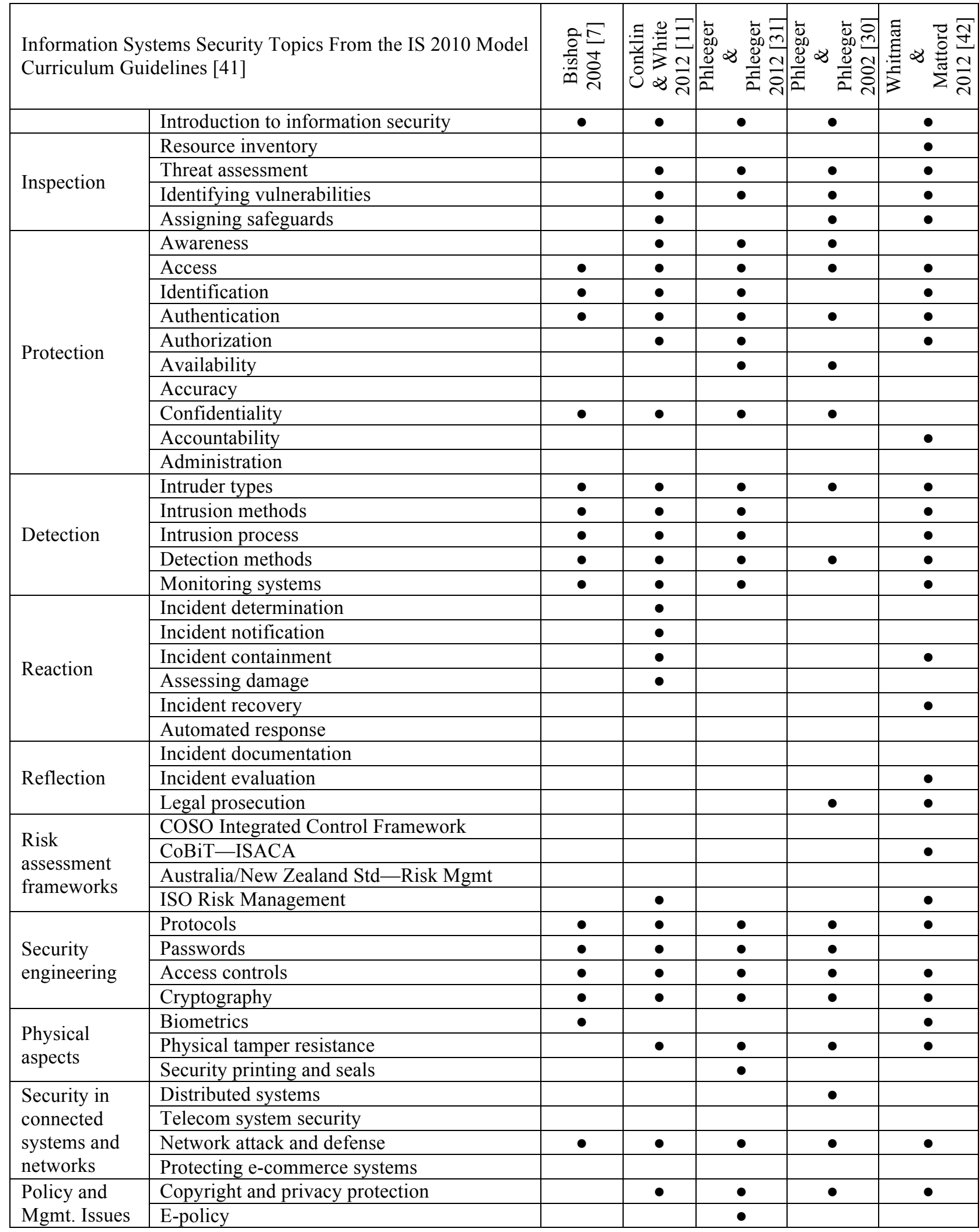




\section{Issues in Information Systems}

Volume 15, Issue II, pp. 39-48, 2014

While IS security textbooks appear to hold little promise in terms of assisting instructors in their globalization efforts directly, supplemental materials to augment core textbooks can provide better coverage of global topics related to information security topics. Specifically, the tables of contents of the five textbooks were searched and compared to the suggested topics from the elective security course in the 2010 model curriculum guidelines [41]. Results show that all topics are not covered by all textbooks, which is not surprising. With respect to textbook topics and chapters, few textbooks explicitly contain information related to globalization or global security events. Each of the topics that appeared in the 2010 model curriculum guidelines [41] and that was covered by all of the IS security textbooks was searched in Google Trends. Results appear in Figure 1 below:

\section{Information Security}

B. "China says it will take measures to uphold its information security in wake of NSA allegations" [9]

M. "Japan firms to start information security rating body" [38]
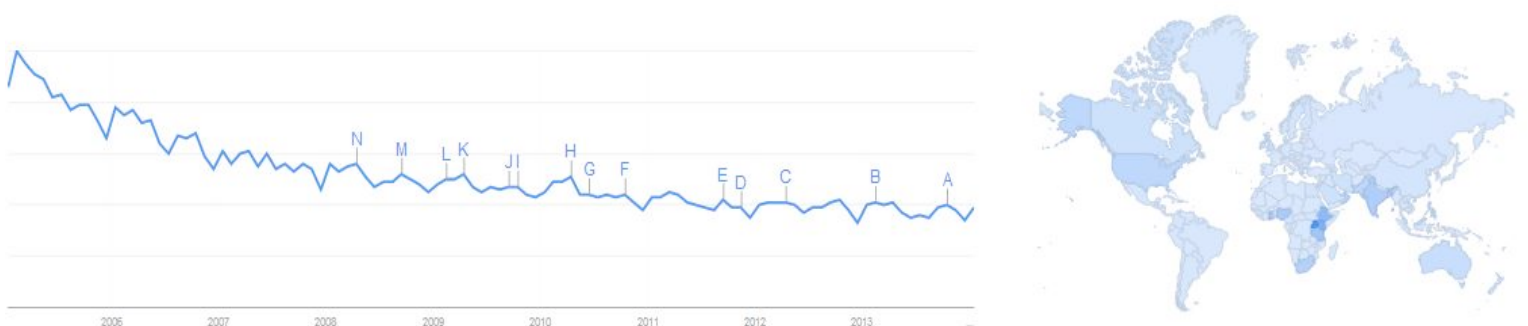

\section{Cryptography}

C. "The Estonian cryptography startup that wants to be the Qualcomm of data security" [3]

D. "Quantum Cryptography done on standard broadband fibre" [27]
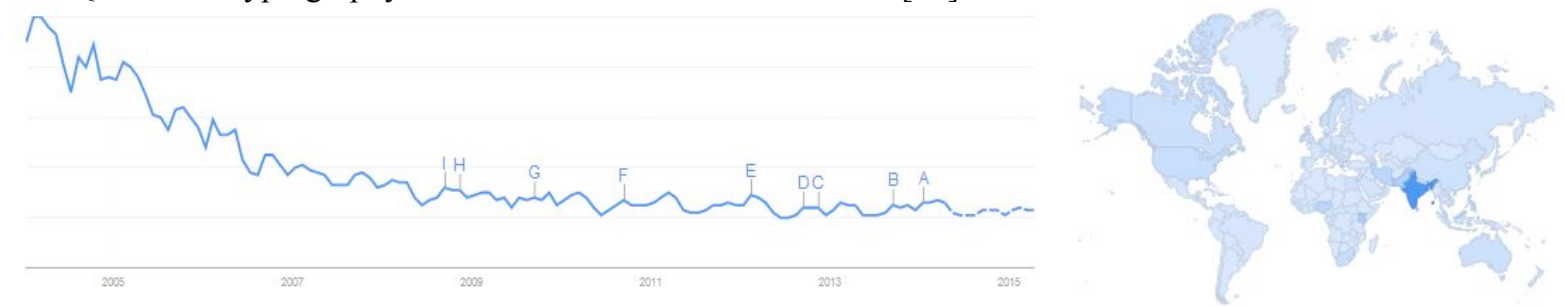

\section{Network Attack}

B. "South Korea Network Attack 'A Computer Virus"” [36]

E. "Sony apologizes, details PlayStation network attack" [44]

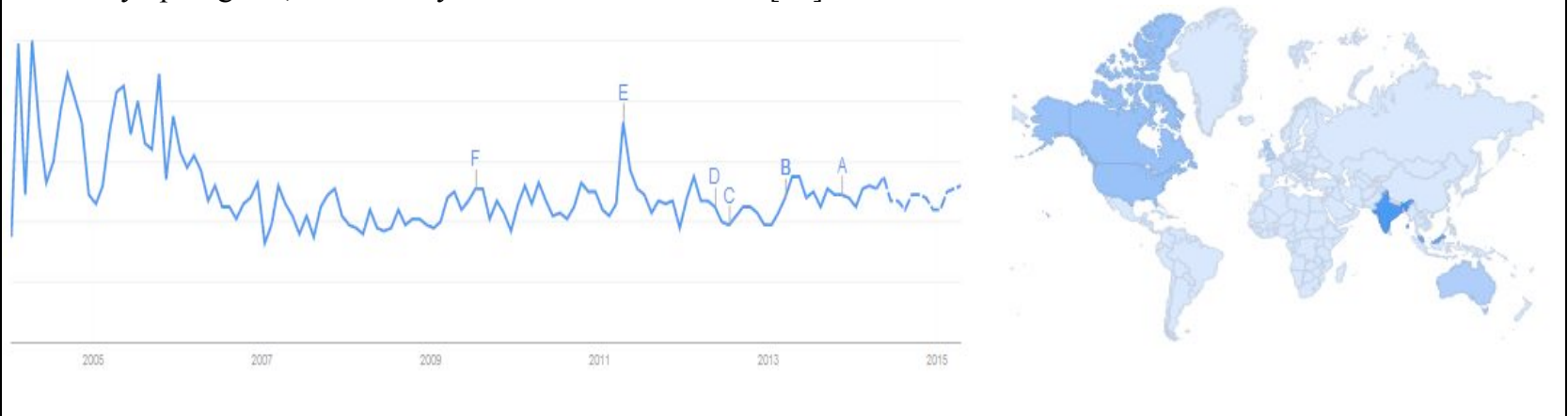

Figure 1. Results for information security terms covered by all IS security text books in the sample

Data collected from Google Trends for each security term topic included search trend graphs over time, forecasted search results if present, global heat maps, and news headlines, if present, which appear as letters in the search trend graphs that appear to drive the peaks in interest in the term. Another way to augment classes is to include news articles, trends and maps for topics that are not included in all texts. Results for data collected from security terms covered by less than half of the IS security text books in the sample appear in Figure 2 on the following page: 
Information Availability

B. "Russia restricts information availability to public" [34]
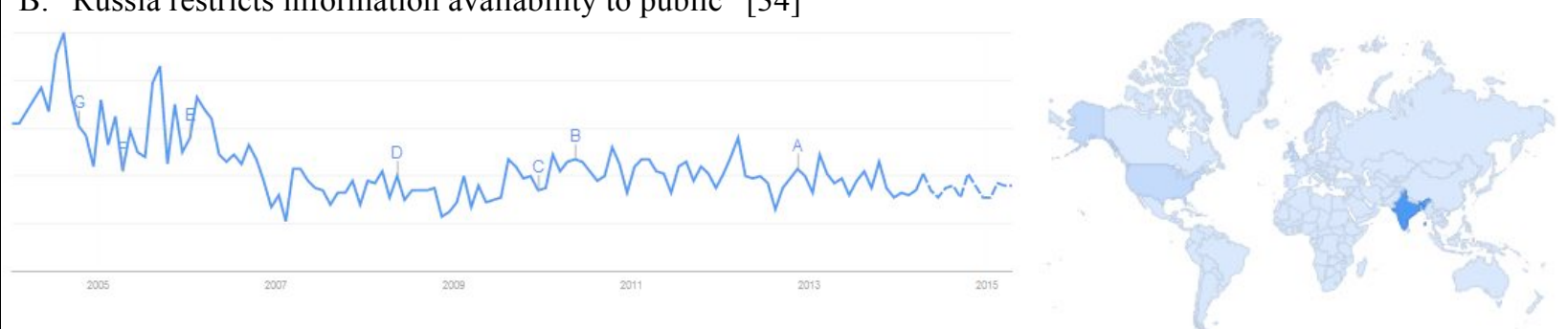

\section{CoBiT}

M. "Opsware Introduces IT Automation Solution to Address European Compliance and Best Practices; Top-Ranked Server Automation System Enables Major Compliance Initiatives Including ITIL and COBiT” [26]
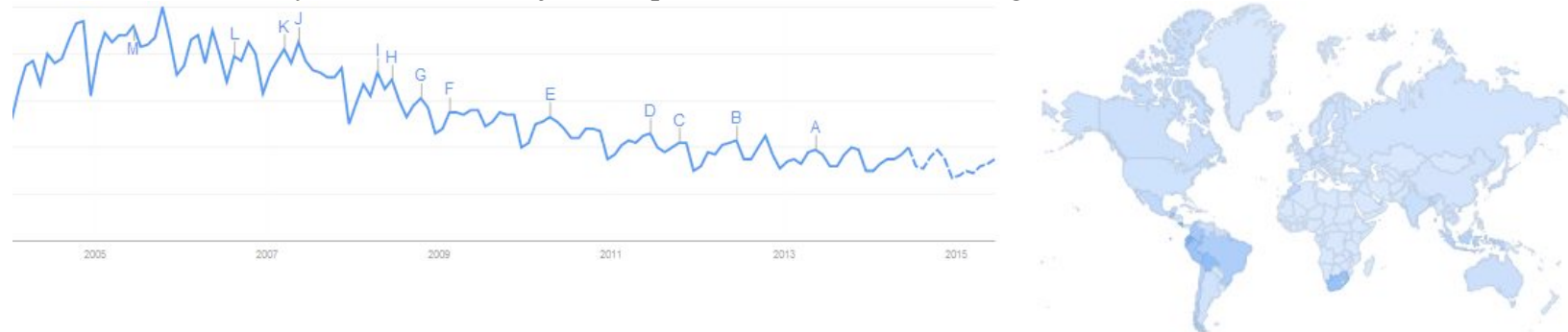

ISO Risk Management
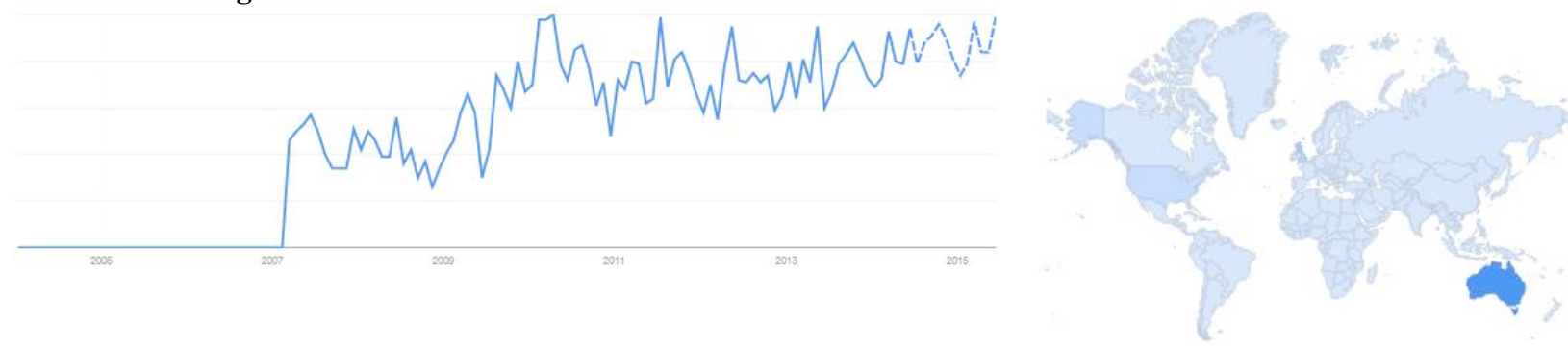

\section{Distributed Systems Security}
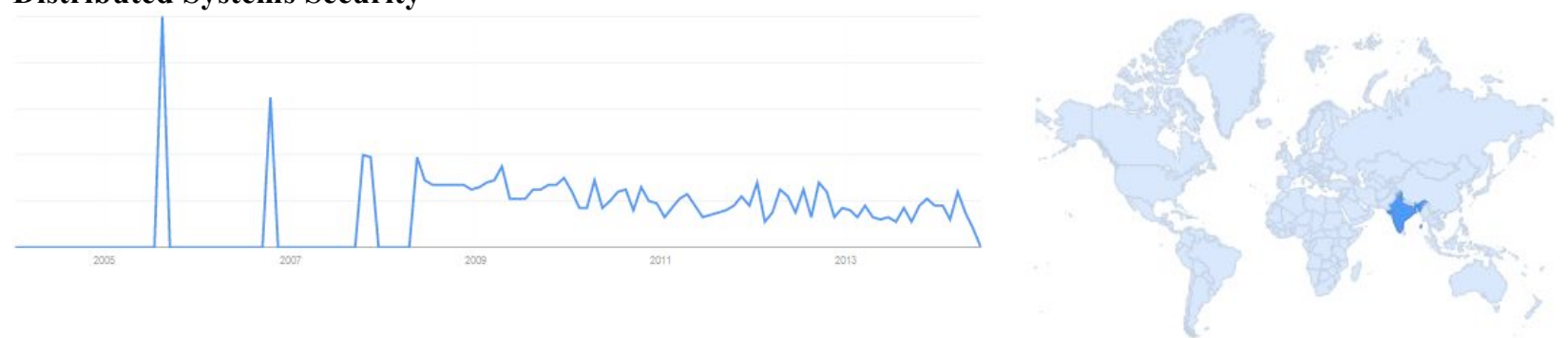

\section{E-Policy}

News results from many countries in many languages deal with aspects of McAfee ePolicy Orchestrator Software
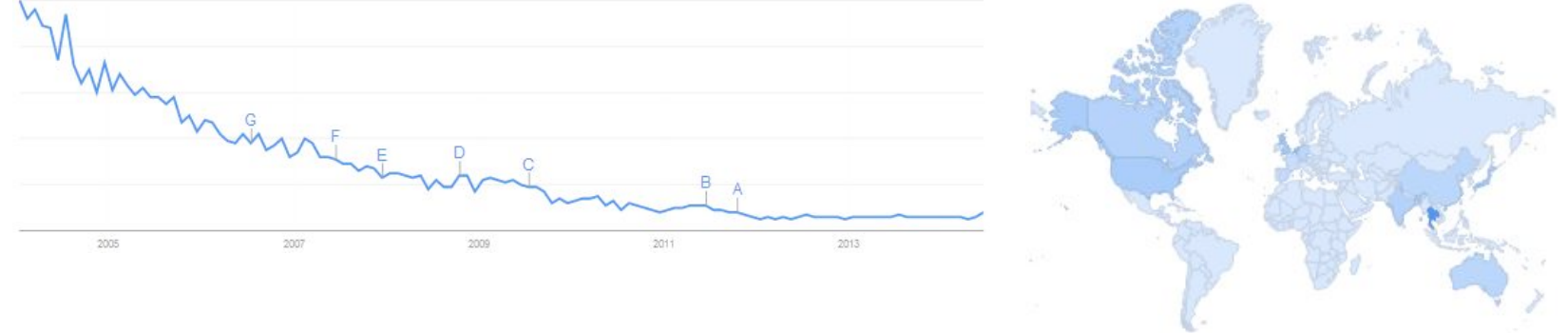

Figure 2. Results for information security terms covered by less than half of the IS security text books in the sample 
Results for data collected from security terms covered by most IS security text books in our sample appear in Figure 2 below:

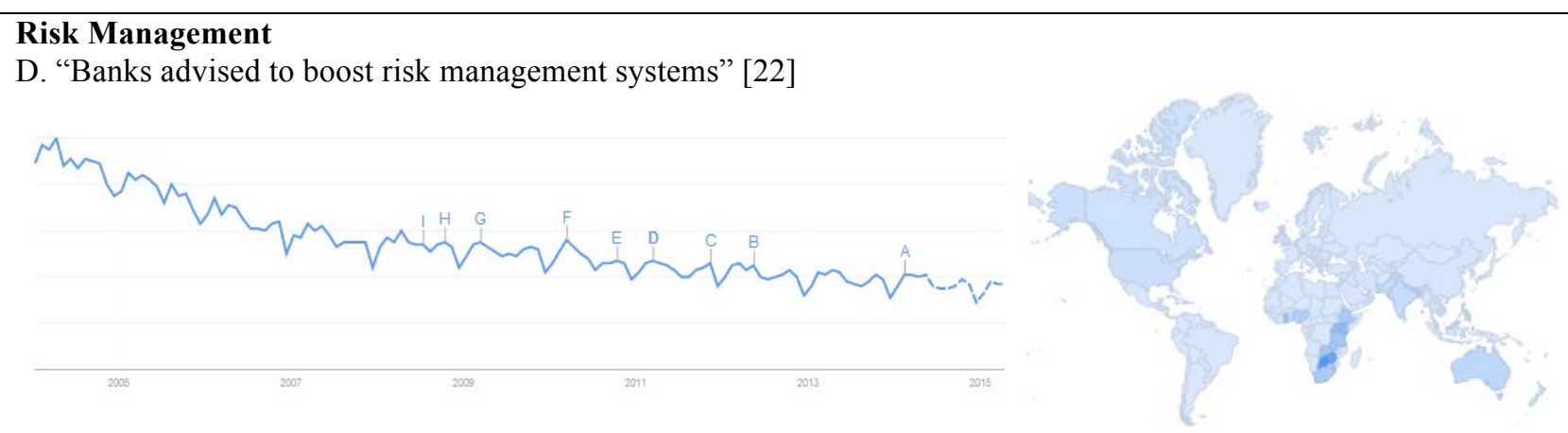

Privacy Policy

C. "Berlin Court: Apple's privacy policy violates German data protection law" [14]

E. "Google implements new privacy law amid criticism" [15]
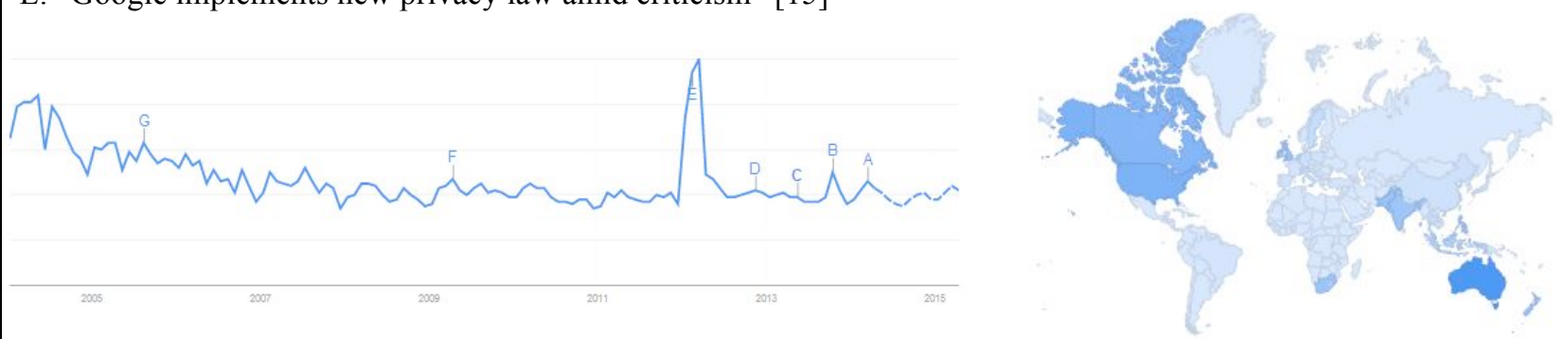

\section{Biometrics}

E. "Safran to buy US biometrics firm for $1.1 \mathrm{bln}$ " [35]

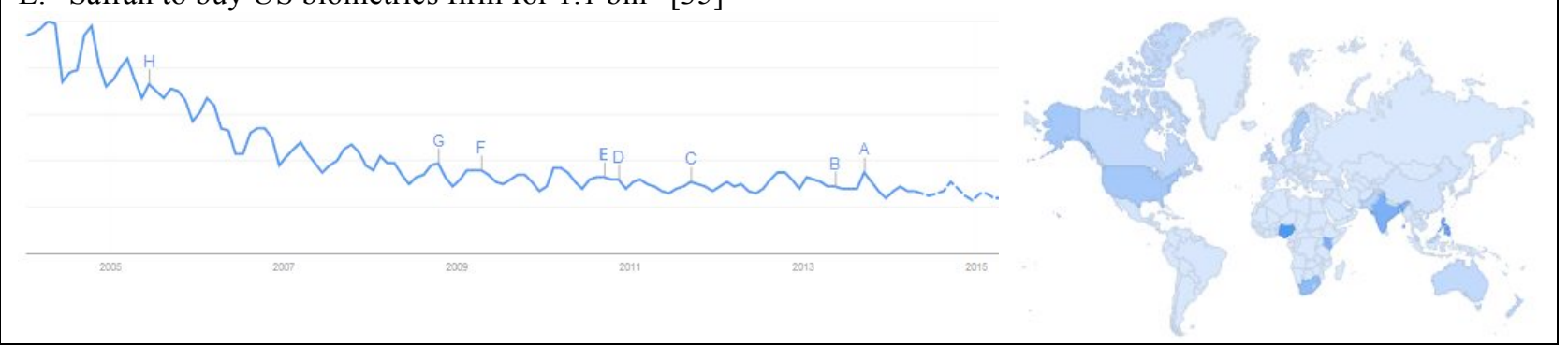

Figure 3. Results for information security terms covered by most IS security text books in the sample

All terms were searched and all data was collected on the same day. Occasionally the term information was added preceding the security topic term in order to disambiguate terms. For example, for the security topic availability, the phrase information availability was searched in order to distinguish results from other forms of the term availability.

\section{CONCLUSIONS}

Recognition of global trends and the importance of globalization, which appeared in the 1997 model curriculum guidelines [12], for undergraduate IS programs, increased slightly across model curriculum guidelines from 2002 and 2010 [16, 41], though there was little, if any, recognition of globalization in the elective IS security course. Yet even an elementary search reveals that security topics associated with information systems is an incredibly global topic. Searches using Google Trends show special attention to IS security-related news items concerning China, Japan, Russia, South Korea, the Republic of Estonia and Germany just to name a few within the last ten years. The usage of the Google Trends tool aids instructors of IS courses in locating supplemental materials like heat maps and 


\section{Issues in Information Systems}

Volume 15, Issue II, pp. 39-48, 2014

related international news articles to use in their classrooms revealing to students the global currency of information systems beyond just textbooks.

Future research will explore the impact of using security-related global heat maps and internationals new stories associated with security-related search trends as modern, global examples of topics covered in typical IS security courses. For example, a follow-up study will ascertain students' understanding of the interconnectedness of information systems globally and gauge whether the inclusion of maps and current events retrieved from Google Trends increases their knowledge and awareness of information systems coursework on the global stage.

Universities are increasingly expanding their international networks and looking to include global perspectives in the classroom [2], which can have a positive impact on revenue and reputation [2]. By supplementing gaps in textbooks with current international news articles and heat maps, instructors can easily globalize their courses. As accreditation standards for colleges of business and curriculum guidelines increasingly recognize globalization in information systems and other business disciplines [1,2], it is imperative to include globalization in courses and study the ability of tools, like Google Trends [32], that help instructors globalize their courses and may impact student learning. It is also important to note that courses beyond those in information systems, and in fact, beyond those in colleges of business, have been called to globalize [28] and can benefit from supplemental news stories and heat maps. The same methodology outlined above can be applied across disciplines, from engineering [2] to computer science and beyond.

\section{REFERENCES}

1. AACSB International (2011, January). Eligibility procedures and accreditation standards for business accreditation. St. Louis.

2. AACSB International (2011), Globalization of management education: Changing international structures, adaptive strategies, and the impact on institutions, Emerald Group Publishing Limited.

3. Aasmae, K. (2013). The Estonian cryptography startup that wants to be the Qualcomm of data security. ZDNet [online]. Available: http://www.zdnet.com/the-estonian-cryptography-startup-that-wants-to-be-the-qualcommof-data-security-7000020216/

4. Adam, N., Awerbuch, A., Slonim, J., Wegner, P., and Yesha, Y. (1997). Globalizing business, education, culture through the Internet. Communications of the ACM, 40(2), 115-121.

5. Aggarwal, A. K., \& Rollier, B. (1994, October). Globalization and the Information Systems Curriculum. In ISECON'94 Proceedings (pp. 70-74).

6. Aggarwal, R. (2011). Developing a global mindset: Integrating demographics, sustainability, technology, and globalization. Journal of Teaching in International Business, 22 (1), 51-69.

7. Bishop, M. (2004). Introduction to Computer Security. Addison-Wesley Professional.

8. Bruner, R. F., \& Iannarelli, J. (2011). Globalization of management education. Journal of Teaching in International Business, 22(4), 232-242.

9. China says it will take measures to uphold its information security in wake of NSA allegations. (2013). Fox News [online]. Available: http://www.foxnews.com/world/2013/10/30/china-says-it-will-take-measures-touphold-its-information-security-in-wake-nsa/

10. Coghlan, T. (2014). Tehran now HQ for global cyber attacks. The Australian. Available: http://www.theaustralian.com.au/news/world/tehran-now-hq-for-global-cyber-attacks/story-fnb64oi61226880339542\#

11. Conklin, A., White, G., Cothren, C., Williams, D., \& Davis, R. L. (2004). Principles of computer security: security + and beyond. McGraw-Hill, Inc..

12. Davis, G. B., Gorgone, J. T., Couger, J. D., Feinstein, D. L., \& Longenecker, Jr, H. E. (1997, December). IS'97: model curriculum and guidelines for undergraduate degree programs in information systems. In ACM SIGMIS Database (Vol. 28, No. 1, pp. 1-94). ACM.

13. Del Vitto, C. (2008). Cross-Cultural "soft skills" and the global engineer: Corporate best practices and trainer methodologies. Online Journal for Global Engineering Education, 3(1), 1.

14. Essers, L. (2013). Berlin court: Apple's privacy policy violates German data protection law. PC World [online]. Available: http://www.pcworld.com/article/2038070/apples-privacy-policy-violates-german-data-protectionlaw-berlin-court-rules.html 


\section{Issues in Information Systems}

Volume 15, Issue II, pp. 39-48, 2014

15. Google implements controversial new privacy policy amid criticism. (2012). The Australian [online]. Available: $\mathrm{http} / /$ www.theaustralian.com.au/technology/google-implements-controversial-new-privacy-policy-amidcriticism/story-e6frgakx-1226286834543\#

16. Gorgone, J., Davis, G. B., Valacich, J. S., Topi, H., Feinstein, D. L., \& Longenecker, H. E. (2003). IS 2002 model curriculum and guidelines for undergraduate degree programs in information systems. Communications of the Association for Information Systems, 11(1), 1.

17. Hedderich, N. (2011). The challenge of transcultural competence: Background reading of target culture current event articles. Global Business Languages, 16.

18. Ibeh, K., Carter, S., Poff, D., \& Hamill, J. (2008). How focused are the world's top-rated business schools on educating women for global management?. Journal of Business Ethics, 83(1), 65-83.

19. Kedia, B. L., \& Englis, P. D. (2011). Internationalizing business education for globally competent managers. Journal of Teaching in International Business, 22(1), 13-28.

20. Kim, S. H., Wang, Q. H., \& Ullrich, J. B. (2012). A comparative study of cyberattacks. Communications of the $A C M$, 55(3), 66-73.

21. Konwar, J., \& Barman, A. (2013). Validating Global Competency Scale for Indian Business and Management Education. Romanian Journal for Multidimensional Education/Revista Romaneasca pentru Educatie Multidimensionala, 5(1), 199-213.

22. Kulabako, Faridah (2011). Banks advised to boost risk management systems. Daily Monitor [online]. Available: http://www.monitor.co.ug/Business/-/688322/1121450/-/3s4a9h/-/

23. Li, Y. (2013). Cultivating Student Global Competence: A Pilot Experimental Study. Decision Sciences Journal of Innovative Education, 11(1), 125-143.

24. Muddiman, A., \& Bainbridge Frymier, A. (2009). What is relevant? Student perceptions of relevance strategies in college classrooms. Communication Studies, 60(2), 130-146.

25. Ojala, M. (2009). The dollar sign: Searching business news. ONLINE: Exploring Technology \& Resources for Information Professionals, 33(2), 44-46.

26. Opsware Introduces IT Automation Solution to Address European Compliance and Best Practices; Top-Ranked Server Automation System Enables Major Compliance Initiatives Including ITIL and COBiT. (2005). Business Wire [online]. Available:

http://www.businesswire.com/portal/site/google/index.jsp?ndmViewId=news_view\&newsId=20050626005028 \&newsLang=en

27. Palmer, J. (2012). Quantum cryptography done on standard broadband fibre. BBC News [online]. Available: http://www.bbc.com/news/science-environment-13940928

28. Parkinson, A. (2009). The rationale for developing global competence. Online Journal for Global Engineering Education, 4(2), 2.

29. Phan, P. (2011). Building the $21^{\text {st }}$ Century Curriculum. BizEd, 38-45.

30. Pfleeger. C. P., \& Pfleeger, S. L. (2002). Security in Computing. Prentice Hall Professional Technical Reference.

31. Pfleeger. C. P., \& Pfleeger, S. L. (2012). Analyzing computer security: A threat/vulnerability/countermeasure approach. Prentice Hall Professional.

32. Rech, J. (2007). Discovering trends in software engineering with google trend. ACM SIGSOFT Software Engineering Notes, 32(2), 1-2.

33. Research shows "dramatic growth" in global cyber attacks. (2013). Infosecurity-Magazine.com [online]. Available: http://www.infosecurity-magazine.com/view/30736/research-shows-dramatic-growth-in-globalcyber-attacks/

34. Russia restricts information availability to public. (2010). Hindustan Times [online]. Available: http://www.hindustantimes.com/world-news/russia-restricts-information-availability-to-public/article1550626.aspx

35. Safran to buy US biometrics firm for $\$ 1.1$ bln. (2010). boston.com [online]. Available: http://www.boston.com/business/articles/2010/09/20/safran_to_buy_us_biometrics_firm_for_11_bln/

36. South Korea network attack 'a computer virus'. (2013). $B B \bar{C}$ News [online]. Available: http://www.bbc.com/news/world-asia-21855051

37. Sikes, V. M. (2010). Current events, the economic downturn and critical pedagogy. Curriculum and Teaching Dialogue, 12.

38. Takenaka, K., \& Tan, B. (2008). Japan firms to start information security rating body. Reuters [online]. Available: http://www.reuters.com/article/2008/04/08/japan-ratings-agency-idUST3741720080408 


\section{Issues in Information Systems}

Volume 15, Issue II, pp. 39-48, 2014

39. Taylor, M., \& White, B. J. (2011). Real world information systems projects in the classroom: Factors to consider. Issues in Information Systems, 12(2), 135-141.

40. Tedford, P. (2003). Using current events as a teaching tool for an undergraduate data structures course. Journal of Computing Sciences in Colleges, 18(4), 50-55.

41. Topi, H., Valacich, J. S., Wright, R. T., Kaiser, K., Nunamaker, Jr., J. F., Sipior, J. C., \& de Vreede, G. J. (2010). IS 2010: Curriculum guidelines for Undergraduate Degree Programs in Information Systems. Communications of the Association for Information Systems, 26, 359-428.

42. Whitman, M. \& Mattord, H. (2012). Principles of Information Security. Boston, MA: Course Technology, Cengage Learning.

43. Willey, L., \& White, B. J. (2013). Do you take credit cards? Security and compliance for the credit card payment industry. Journal of Information Systems Education, 24(3), 181-188.

44. Williams, M. (2011). Sony apologizes, details PlayStation Network attack. Computer World [online\}. Available:http://www.computerworld.com/s/article/9216311/Sony_apologizes_details_PlayStation_Network_at tack 